\title{
Relative roles of phototherapy and phenobarbitone in treatment of nonhaemolytic neonatal jaundice
}

\author{
Y. K. WONG and B. S. B. WOOD \\ From the Birmingham Maternity Hospital, Queen Elizabeth Medical Centre, Birmingham
}

\begin{abstract}
Wong, Y. K., and Wood, B. S. B. (1973). Archives of Disease in Childhood, 48, 704. Relative roles of phototherapy and phenobarbitone in treatment of nonhaemolytic neonatal jaundice. Trials were carried out on 61 infants with plasma bilirubin over $15 \mathrm{mg} / 100 \mathrm{ml}$ to compare effects of phototherapy alone, phenobarbitone by injection, and both treatments combined. Infants above $2.5 \mathrm{~kg}$ birthweight treated with phenobarbitone only behaved like untreated controls up to 60 hours, and only at 84 hours was a significant fall seen. Infants of $2.5 \mathrm{~kg}$ birthweight or less treated with phenobarbitone had significantly higher levels throughout the 84 hours of study. Phototherapy, either alone or combined with phenobarbitone, had its expected significant effect from 24 hours onwards in both groups of infants. Combined phototherapy and phenobarbitone treatment showed no difference from phototherapy alone. Phenobarbitone has no place in the management of established jaundice. Risks of phenobarbitone therapy and a possible explanation of contradictory results in previous trials are discussed. No changes were found in packed cell volumes, plasma albumin level, or residual albumin binding capacity at 48 hours from onset of treatment or between groups.
\end{abstract}

Since Trolle (1968a, b) suggested the use of phenobarbitone for treatment of neonatal hyperbilirubinaemia, a number of trials (Maurer et al., 1968; Trolle, 1968b; Ramboer, Thompson, and Williams, 1969; Valaes, Petmezaki, and Doxiadis, 1970; Vest et al., 1970; Stern et al., 1970; McMullin, Hayes, and Arora, 1970; Yeung et al., 1971) have shown that its administration to the mother before birth or to the infant soon after birth produced a significant reduction in plasma bilirubin levels from the 2nd to the 4th days of life. Phenobarbitone therapy started after the appearance of jaundice seemed to be far less effective, though some studies (Yeung and Field, 1969; Stern et al., 1970; Sinniah, Tay, and Dugdale, 1971) have shown reduced need for exchange transfusions and lower plasma bilirubin levels, while others (Levin, McMullin, and Mobarak, 1970; Cunningham, Mace, and Peters, 1969) have found no significant difference.

The possible adverse effects of phenobarbitone on the neonate have been reviewed by Wilson (1969). There are theoretical risks that the liver cells affected by phenobarbitone may become more susceptible to hepatotoxic drugs or that an increase in microsomal

Received 9 February 1973. enzyme activity may accelerate the metabolism of certain drugs rendering them less effective (Burns, 1964; Fouts, 1964; Conney, 1967). Sexual and behavioural development might be affected as a consequence of possible alteration in steroid metabolism (Conney and Klutch, 1963; Kuntzman et al., 1964; Kuntzman, Lawrence, and Conney, 1965). Large doses of barbiturates in mothers have also been reported to produce coagulation defects in newborn infants (Schulz and van Creveld, 1958; Mountain, Hirsh, and Gallus, 1970). As the excretion of barbiturates in the newborn is extremely variable (Melchior, Svensmark, and Trolle, 1967), significant levels may be present in some infants for days or weeks while others excrete the drug within 2 days. Intravenous barbiturates used for sedation in labour can affect the infant's ability to suck and lead to reduced milk intake (Kron, Stein, and Goddard, 1966). To date, however, no immediate or serious side effects have been reported from the clinical trials in which phenobarbitone was given to mothers and infants, though no long-term follow-up report has yet been published.

It was therefore decided to compare phenobarbitone treatment with phototherapy for the treatment of jaundice. Phototherapy has been 
shown to be effective (Broughton et al., 1965; Lucey, Ferreiro, and Hewitt, 1968; Behrman and Hsia, 1969) even when treatment was not started until significant jaundice (plasma bilirubin $>15 \mathrm{mg} / 100$ $\mathrm{ml}$ ) had developed (Wong, Shuttleworth, and Wood, 1972). Furthermore, since the known mechanisms for reduction of jaundice by phenobarbitone and phototherapy are unrelated, it was decided to study the effect of these 2 treatments combined.

\section{Materials and methods}

Only those infants whose plasma bilirubin levels rose to $15 \mathrm{mg} / 100 \mathrm{ml}$ and above were included. Infants with the following conditions were excluded. (i) Infants with rhesus haemolytic disease. (ii) Group A or B infants whose mothers were group $O$. (iii) Infants of diabetic mothers. (iv) Breast-fed infants. (v) Infants with any evidence of infection. Infants weighing $2.5 \mathrm{~kg}$ or less at birth were considered separately. The babies were allocated to one of three regimens by random selection.

I. Phototherapy for 60 hours.

II. Administration of phenobarbitone sodium BP by 3 daily intramuscular injections at a dosage of $\mathbf{8}$ $\mathrm{mg} / \mathrm{kg}$ per day for a total of 10 doses.

III. Combined treatment as in I and II.

It was not considered ethical to have controls, as results from a previous trial (Wong et al., 1972) had shown that about a third of the controls required therapy because the bilirubin level was rising to $20 \mathrm{mg} / 100 \mathrm{ml}$. 8 babies from a previous trial were therefore used as controls.

Total bilirubin was measured by the spectrophotometric method of Scott (1959). Plasma albumin was measured by a modification of the bromocresol green dye binding method of Bartholomew and Delaney (1966). Residual albumin binding capacity (RABC) was measured using the HBABA dye method of Porter and Waters (1966) and was expressed as $g$ albumin reserve/100 ml plasma (Wood, Comley, and Sherwell, 1970).

\section{Results}

Infants above $2.5 \mathrm{~kg}$ birthweight (Trial A). 14 infants were entered into the trial in each group and the mean values of birthweight, gestation, and age at onset of phototherapy in each group, with 1 $S D$, are shown in Table I.
All infants who received only phototherapy responded satisfactorily and no further treatment was required. Of the group given phenobarbitone alone, $3 \mathrm{had}$ bilirubin levels reaching $20 \mathrm{mg} / 100 \mathrm{ml}$ and were given other treatment, leaving 11 for comparison. In the combined group 1 infant was given an exchange transfusion as the bilirubin rose to $20 \mathrm{mg} / 100 \mathrm{ml}$, while 2 infants developed severe infections 36 to 48 hours after onset of treatment (see Discussion) so that again 11 were left. Of the 8 infants in the control group, 3 had to be given treatment as their bilirubin levels reached $20 \mathrm{mg} / 100$ $\mathrm{ml}$, leaving only 5 for comparison in the results.

The mean drop or rise was obtained by calculating the difference from the pretreatment level in each infant and then averaging the sum of the differences. The significance of the mean between groups was calculated using Student's ' $t$ ' test. All results on differences were calculated in this way.

The changes in bilirubin levels are shown in Fig. 1 , while the alterations in plasma albumin levels and

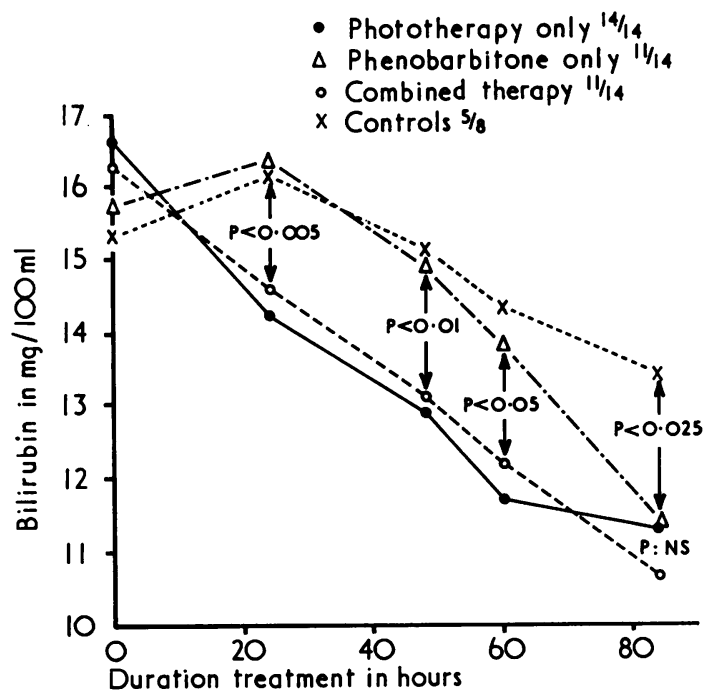

FIG. 1.-Bilirubin levels in infants above $2.5 \mathrm{~kg}$ birthweight in Trial $A$.

TABLE I

Group comparability in infants over $2.5 \mathrm{~kg}$ birthweight (Trial $A$ )

\begin{tabular}{|c|c|c|c|c|}
\hline Groups & No. & $\begin{array}{l}\text { Mean birthweight } \\
(\mathbf{k g})(\mathrm{SD})\end{array}$ & $\begin{array}{l}\text { Mean gestation } \\
(\mathbf{w k})(\mathrm{SD})\end{array}$ & $\begin{array}{l}\text { Mean age at onset of } \\
\text { treatment (hr) SD) }\end{array}$ \\
\hline $\begin{array}{l}\text { Combined } \\
\text { Phototherapy only } \\
\text { Phenobarbitone only } \\
\text { Controls }\end{array}$ & $\begin{array}{c}11 / 14 \\
14 / 14 \\
11 / 14 \\
5 / 8\end{array}$ & $\begin{array}{l}3.02(0.357) \\
3 \cdot 27(0.503) \\
3.04(0.386) \\
3.39(0.699)\end{array}$ & $\begin{array}{l}37 \cdot 8(1 \cdot 537) \\
39 \cdot 0(1 \cdot 414) \\
38 \cdot 6(1 \cdot 293) \\
38 \cdot 6(1 \cdot 95)\end{array}$ & $\begin{array}{l}84 \cdot 8(22 \cdot 4) \\
84 \cdot 8(20 \cdot 2) \\
85 \cdot 5(12 \cdot 2) \\
83 \cdot 4(15 \cdot 6)\end{array}$ \\
\hline
\end{tabular}

Note: Differences between mean values are not significant. $\mathrm{SD}$, standard deviation. 
residual albumin binding capacity (RABC) are shown in Table II.

\section{TABLE II}

Plasma albumin and residual albumin binding capacity levels in infants over $2.5 \mathrm{~kg}$ birthweight (Trial A)

\begin{tabular}{l|c|c}
\hline \multicolumn{1}{c|}{ Groups } & \multicolumn{2}{|c}{ Mean differences after 48 hours (1 SD) } \\
\cline { 2 - 3 } & $\begin{array}{c}\text { Plasma albumin } \\
(\mathrm{g} / 100 \mathrm{ml})\end{array}$ & RABC $(\mathrm{g} / 100 \mathrm{ml})$ \\
\hline $\begin{array}{l}\text { Combined } \\
\text { Phototherapy only }\end{array}$ & $\begin{array}{l}+0.09(0.217) \\
+0.15(0.303) \\
+0.03(0.295)\end{array}$ & $\begin{array}{l}+0.17(0.295) \\
+0.30(0.299) \\
+0.19(0.281)\end{array}$ \\
\hline
\end{tabular}

Note: Differences are not significant.

Packed cell volume (PCV) was also estimated but did not show any significant differences between the groups.

\section{Infants $2.5 \mathrm{~kg}$ birthweight and below (Trial} B). This trial was carried out on a total of 19 infants. Table III shows their comparability. No controls could be justified. 1 infant was removed from the phenobarbitone group because of rising bilirubin levels and the results are based on 6 infants in each group.

The changes in the various levels are shown in Fig. 2 and Table IV. Again there were no significant differences in the PCV between groups.

\section{Discussion}

In both trials the only differences between the groups lay in the bilirubin levels.

Despite higher starting levels, the group on phototherapy only and the combined groups had significantly lower bilirubin levels than both the control and the phenobarbitone groups within 24 hours of onset of treatment, and this was maintained at 60 hours. In the infants over $2.5 \mathrm{~kg}$ (Trial A) the phenobarbitone group fell no faster than the controls up to 60 hours, but at 84 hours the bilirubin level had fallen close to that of the other 2 treated

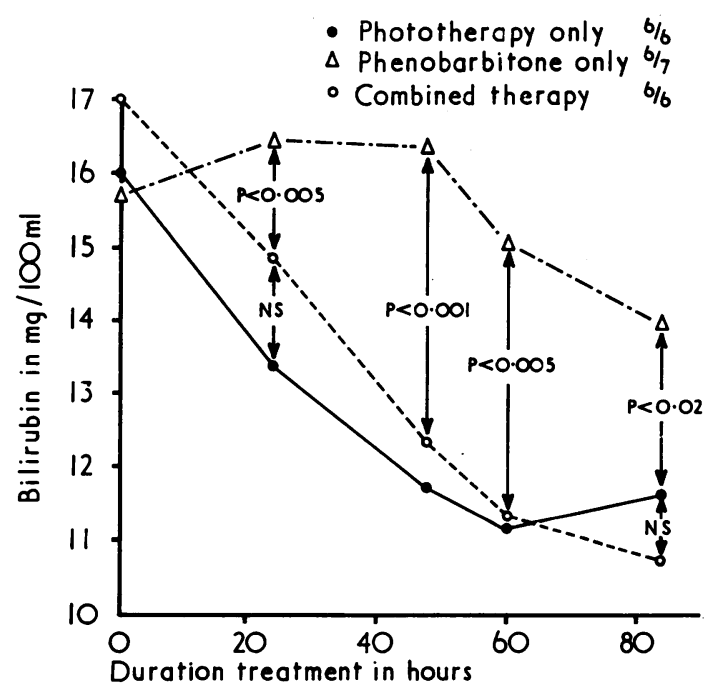

FIG. 2.-Bilirubin levels in infants of $2.5 \mathrm{~kg}$ birthweight or less in Trial $B$.

\section{TABLE IV}

Plasma albumin and residual albumin binding capacity levels in infants of $2.5 \mathrm{~kg}$ birthweight or less (Trial B)

\begin{tabular}{l|l|l}
\hline \multicolumn{1}{c|}{ Groups } & \multicolumn{2}{|c|}{ Mean differences after 48 hours (1 SD) } \\
\cline { 2 - 3 } & $\begin{array}{c}\text { Plasma albumin } \\
(\mathrm{g} / 100 \mathrm{ml})\end{array}$ & RABC $(\mathrm{g} / 100 \mathrm{ml})$ \\
\hline $\begin{array}{l}\text { Combined } \\
\text { Phototherapy only } \\
\text { Phenobarbitone only }\end{array}$ & $\begin{array}{l}+0.033(0.362) \\
+0.067(0.25) \\
-0.04(0.305)\end{array}$ & $\begin{array}{l}+0.15(0.198) \\
+0.30(0.342) \\
-0.06(0.055)\end{array}$ \\
\hline
\end{tabular}

Note: Differences are not significant.

groups. The smaller infants $(2.5 \mathrm{~kg}$ and under), however, showed no such fall even at 84 hours. This suggests that while the larger, presumably more mature, baby will respond to phenobarbitone after 60 hours, the low birthweight infant fails to do so up to 84 hours. This accords with the report of Sinniah et al. (1971). Because of this considerable time lag of 48 to 60 hours during which 4 infants had

TABLE III

Group comparability in infants of $2.5 \mathrm{~kg}$ birthweight or less (Trial B)

\begin{tabular}{|c|c|c|c|c|}
\hline Groups & No. & $\begin{array}{l}\text { Mean birthweight } \\
(\mathrm{kg})(\mathrm{SD})\end{array}$ & $\begin{array}{l}\text { Mean gestation } \\
\quad(w k)(S D)\end{array}$ & $\begin{array}{l}\text { Mean age at onset of } \\
\text { treatment (hr) (SD) }\end{array}$ \\
\hline $\begin{array}{l}\text { Combined } \\
\text { Phototherapy only } \\
\text { Phenobarbitone only }\end{array}$ & $\begin{array}{l}6 / 6 \\
6 / 6 \\
6 / 7\end{array}$ & $\begin{array}{l}2 \cdot 01(0 \cdot 232) \\
2 \cdot 17(0 \cdot 088) \\
2 \cdot 04(0 \cdot 298)\end{array}$ & $\begin{array}{l}34 \cdot 3(1 \cdot 862) \\
34 \cdot 5(0 \cdot 548) \\
34 \cdot 3(2 \cdot 06)\end{array}$ & $\begin{array}{l}93 \cdot 8(18 \cdot 2) \\
9 \cdot 38(3 \cdot 1) \\
9 \cdot 48(17 \cdot 2)\end{array}$ \\
\hline
\end{tabular}

Note: Differences are not significant. $\mathrm{SD}$, standard deviation. 


\section{Roles of phototherapy and phenobarbitone in treatment of nonhaemolytic neonatal jaundice 707}

to be given other treatment, it appears that in clinical practice the effect of phenobarbitone is too slow to control a rising plasma bilirubin level once it has reached $15 \mathrm{mg} / 100 \mathrm{ml}$ or more.

Combining phototherapy with phenobarbitone did not produce any difference in bilirubin levels compared with phototherapy alone throughout the 60 hours of phototherapy. The rate of fall from 60 to 84 hours appeared faster in the combined groups compared with phototherapy only (Fig. 1 and 2), but the end points did not differ significantly.

Our results on combined therapy of infants $>2.5 \mathrm{~kg}$ birthweight are in agreement with the findings of Valdes et al. (1971) and Blackburn, Orzalesi, and Pigram (1972) who showed no difference in plasma bilirubin levels when compared with those treated with phototherapy alone. In these studies, however, treatment was started within 24 hours after birth.

There were 2 deaths in the present trial; both received phenobarbitone combined with phototherapy. They were apparently normal healthy term neonates, but one developed septicaemia and the other meningitis after 36 hours. It is not possible to state categorically that the infections were nut present before entry into the trial, but there were no signs apart from jaundice. However, the delay in diagnosis may have been partly due to phenobarbitone, which could modify or even totally suppress any fits, and partly due to difficulty in the assessment of subtle changes in the infants colour, e.g. cyanosis, once the infant is under the light. In view of this possibility and the results showing the combined therapy to be no different from phototherapy alone, the former treatment cannot be recommended. It is also suggested that infants under phototherapy should be kept under close scrutiny since jaundice may be the only sign of neonatal infection.

No immediate side effects were found in the other treated groups. The dosage of phenobarbitone given did not cause any lethargy or difficulties with respiration or feeding.

The present results obtained with phenobarbitone therapy in infants over $2.5 \mathrm{~kg}$ birthweight are in general agreement with the findings of Yeung and Field (1969), Stern et al. (1970), and Sinniah et al. (1971). They differ from those of Levin et al. (1970) and Cunningham et al. (1969) who administered phenobarbitone orally 5 to $15 \mathrm{mg} /$ day for 3 days to infants who appeared jaundiced (plasma bilirubin level around $8 \mathrm{mg} / 100 \mathrm{ml}$ ) and found no significant drop of bilirubin when compared to controls.

Such contradictory findings may be explained in part by the following considerations. With the exception of the present trial, all others quoted administered oral phenobarbitone. The possibility of variable absorption or vomiting of oral medication cannot be excluded. Furthermore, phenobarbitone itself is virtually insoluble in water and elixir phenobarbitone BP contains $36 \%$ ethanol $v / v$, so that infants weighing $3 \mathrm{~kg}$ who are given $8 \mathrm{mg} / \mathrm{kg}$ per day of elixir phenobarbitone would thus receive over $3 \mathrm{ml}$ of $90 \%$ ethanol. Ethanol itself has been shown to have a similar effect to phenobarbitone when administered to the mother in the prevention of hyperbilirubinaemia in the newborn (Waltman et al., 1969). In the study of Levin et al. (1970) phenobarbitone was given in linctus simplex (which also contains ethanol) and the controls also received linctus simplex, so that both groups received some form of enzyme inducer. In other studies phenobarbitone 'syrup' was given with no reference as to whether the controls received any syrup or not. It is probable that some of these infants received elixir phenobarbitone (with ethanol as vehicle) while others received phenobarbitone in another solvent or in a suspension. The differences in the findings could well be explained in this way.

Certain preparations of phenobarbitone sodium BP for injection contain alcohol, but in the present study phenobarbitone sodium BP (McCarthy's Ltd.) was used with propylene glycol as the vehicle, which has been shown to have no enzyme induction properties (Zarolinski, Browne, and Possley, 1971).

We gratefully acknowledge support for one of us (Y.K.W.) by the Endowment Fund of the United Birmingham Hospitals. Dr. John Waterhouse gave much help and advice on the statistical side of the study. We are grateful to the residents and nursing staff of the neonatal unit at the Birmingham Maternity Hospital for care of the infants during the period.

\section{REPBRENCES}

Bartholomew, R. J., and Delaney, A. M. (1966). Sulphonphthaleins as specific reagents for albumin: determination of albumin in serum. Proceedings of the Australian Association of Clinical Biochemists, 1, 214.

Behrman, R. E., and Hsia, D. Y. Y. (1969). Summary of a symposium on phototherapy for hyperbilirubinaemia. Fournal of Pediatrics, 75, 718.

Blackburn, M. G., Orzalesi, M. M., and Pigram, P. (1972). The combined effect of phototherapy and phenobarbital on serum bilirubin levels of premature infants. Pediatrics, 49, 110.

Broughton, P. M. G., Rossiter, E. J. R., Warren, C. B. M., Goulis, G., and Lord, P. S. (1965). Effect of blue light on hyperbilirubinaemia. Archives of Disease in Childhood, 40, 666.

Burns, J. J. (1964). Implications of enzyme induction for drug therapy. American fournal of Medicine, 37, 327.

Conney, A. H. (1967). Pharmacological implications of microsomal enzyme induction. Pharmacological Reviews, 19, 317.

Conney, A. H., and Klutch, A. (1963). Increased activity of androgen hydroxylases in liver microsomes of rats pretreated with phenobarbital and other drugs. Fournal of Biological Chemistry, 238, 1611. 
Cunningham, M. D., Mace, J. W., and Peters, E. R. (1969). Clinical experience with phenobarbitone in icterus neonatorum. Lancet, 1, 550.

Fouts, J. R. (1964). Drug interactions: effects of drugs and chemicals on drug metabolism. Gastroenterology, 46, 486.

Kron, R. E., Stein, M., and Goddard, K. B. (1966). Newborn sucking behaviour affected by obstetric sedation. Pediatrics, 37, 1012.

Kuntzman, R., Jacobson, M., Schneidman, K., and Conney, A. H. (1964). Similarities between oxidative drug-metabolizing enzymes and steroid hydroxylases in liver microsomes. Fournal of Pharmacology and Experimental Therapeutics, 146, 280.

Kuntzman, R., Lawrence, D., and Conney, A. H. (1965). Michaelis constants for the hydroxylation of steroid hormones and drugs by rat liver microsomes. Molecular Pharmacology, 1, 163.

Levin, G. E., McMullin, G. P., and Mobarak, A. N. (1970). Controlled trial of phenobarbitone in neonatal jaundice. Archives of Disease in Childhood, 45, 93.

Lucey, J., Ferreiro, M., and Hewitt, J. (1968). Prevention of hyperbilirubinaemia of prematurity by phototherapy. Pediatrics, 41, 1047.

McMullin, G. P., Hayes, M. F., and Arora, S. C. (1970). Phenobarbitone in rhesus haemolytic disease; a controlled trial Lancet, 2, 949.

Maurer, H. M., Wolff, J. A., Finster, M., Poppers, P. J., Pantuck, E. Kuntzman, R., and Conney, A. H. (1968). Reduction in concentration of total serum-bilirubin in offspring of women treated with phenobarbitone during pregnancy. Lancet, 2, 112.

Melchior, J. C., Svensmark, O., and Trolle, D. (1967). Placental transfer of phenobarbitone in epileptic women and elimination in newborns. Lancet, $2,860$.

Mountain, K. R., Hirsh, J., and Gallus, A. S. (1970). Neonatal coagulation defect due to anticonvulsant drug treatment in pregnancy. Lancet, 1, 265.

Porter, E. G., and Waters, W. J. (1966). A rapid micromethod for measuring the reserve albumin binding capacity in serum from newborn infants with hyperbilirubinaema. Fournal of Laboratory and Clinical Medicine, 67, 660.

Ramboer, C., Thompson, R. P. H., and Williams R. (1969), Controlled trials of phenobarbitone therapy in neonatal jaundice. Lancet, 1, 966.

Schulz, J., and Creveld, S., van (1958). Stuart-Prower factor in newborn infants. Etudes NÉo-natales, 7, 133.

Scott, P. (1959). An ultramicromethod for the estimation of plasma bilirubin in neonates. Newsletter of the Association of Clinical Biochemists, No. 24, November 1959, p. 11.

Sinniah, D., Tay, L. K., and Dugdale, A. E. (1971). Phenobarbitone in neonatal jaundice. Archives of Disease in Childhood, 46, 712
Stern, L., Khanna, N., Levy, G., and Yaffe, S. J. (1970). Effect of phenobarbital on hyperbilirubinaemia and glucuronide formation in newborns. American foumal of Diseases of Children, 120, 26.

Trolle, D. (1968a). Phenobarbitone and neonatal icterus. Lancet, $1,251$.

Trolle, D. (1968b). Decrease of total serum-bilirubin concentration in newborn infants after phenobarbitone treatment. Lancet, 2 705.

Valaes, T., Petmezaki, S., and Doxiadis, S. A. (1970). Effect on neonatal hyperbilirubinaemia of phenobarbital during pregnancy or after birth: practical value of the treatment in a population with high risk of unexplained severe neonatal jaundice. In Bilirubin Metabolism in the Newborn. (Birth Defects, Original Articles Series Vol. 6, No. 2), p. 46. Ed. by D. Bergsma. Williams and Wilkins (for National FoundationMarch of Dimes), Baltimore.

Valdes, O. S., Maurer, H. M., Shumway, C. N., Draper, D. A., and Hossaini, A. A. (1971). Controlled clinical trial of phenobarbital and/or light in reducing neonatal hyperbilirubinemia in a predominantly negro population. Fournal of Pediatrics, 78 , 1015.

Vest, M. F., Signer, E., Weisser, K., and Olafsson, A. (1970). A double blind study of the effect of phenobarbitone on neonatal hyperbilirubinaemia and frequency of exchange transfusion. Acta Paediatrica Scandinavica, 59, 681.

Waltman, R., Bonura, F., Nigrin, G., and Pipat, C. (1969). Ethanol in prevention of hyperbilirubinaemia in the newborn. Lancet, 2, 1265.

Wilson, J. T. (1969). Phenobarbitone in the perinatal period. Pediatrics, 43, 324.

Wong, Y. K., Shuttleworth, G. R., and Wood, B. S. B. (1972). Effect of albumin administration on phototherapy for neonatal jaundice. Archives of Disease in Childhood, 47, 241.

Wood, B., Comley, A., and Sherwell, J. (1970). Effect of additions? albumin administration during exchange transfusion on plasma albumin-binding capacity. Archives of Disease in Childhoud, 45, 59.

Yeung, C. Y., and Field, C. E. (1969). Phenobarbicone therapy in neonatal hyperbilirubinaemia. Lancet, 2, 135 .

Yeung, C. Y., Tam, L. S., Chan, A., and Lee, X. H. (1971). Phenobarbitone prophylaxis for neonctal hyperbilirubinemia. Pediatrics, 48, 372.

Zarolinski, J. F., Browne, R. K., and Possley, L. H. (1971). Propylene glycol as a drug solvent in pharmacologic studies. Toxicology and Applied Pharmacology, 19, 573.

Correspondence to Dr. B. S. B. Wood, The Children's Hospital, Ladywood Middleway, Birmingham B16 8ET. 